\title{
Effect of Fruiting and Biennial Bearing Potential on Spur Quality and Leaf Gas Exchange in Apple
}

\author{
Mokhles A. Elsysy \\ Department of Horticulture and Landscape Architecture, Purdue University, 625 Agriculture Mall \\ Drive, West Lafayette, IN 47907; and Department of Pomology, College of Agriculture, Assiut \\ University, Assiut 71515, Egypt \\ Michael V. Mickelbart \\ Department of Horticulture and Landscape Architecture, Purdue University, 625 Agriculture Mall \\ Drive, West Lafayette, IN, 47907; and Department of Botany and Plant Pathology, Purdue University, \\ 915 W. State Street, West Lafayette, IN 47907 \\ Peter M. Hirst ${ }^{1}$ \\ Department of Horticulture and Landscape Architecture, Purdue University, 625 Agriculture Mall \\ Drive, West Lafayette, IN 47907
}

\begin{abstract}
ADDITIONAL INDEX wORDs. flower formation, transpiration
Abstract. Uniform annual apple (Malus $\times$ domestica) fruit production is highly dependent on consistent flower formation from year to year, as inconsistent flowering can lead to the biennial bearing observed in some high-value cultivars. The presence of fruit on a spur has been considered the main cause of the expression of biennial bearing and the inhibition of flower initiation, with a number of theories being introduced to explain the phenomenon. In the current experiment, individual spurs of annual bearing cultivars (Gala, Ruby Jon, and Pink Lady) and biennial bearing cultivars (Honeycrisp, Fuji, and Golden Delicious) were thinned to a single fruit or completely defruited at petal fall. Spurs were sampled at the end of the growing season. Effects of fruiting on spur characteristics such as spur and bourse leaf area, stomatal density, leaf gas exchange, and flower formation were determined. Across all cultivars, the presence of fruit on a spur did not affect spur characteristics or flower formation compared with nonfruiting spurs. Similarly, flowering was unaffected by those factors associated with greater spur carbohydrate status, such as bourse leaf area and assimilation rate. Cultivars with greater transpiration and stomatal conductance $\left(g_{s}\right)$ rates had lower rates of flower formation. Future studies should focus on xylem flow and expression of genes regulating flowering and plant growth regulators in annual and biennial bearing cultivars.
\end{abstract}

One of the most challenging problems associated with fruit tree production is biennial bearing. Biennial bearing is "the fluctuation in cropping from year-to-year caused by irregular flowering" (Hirst, 2017). Considerable research has been conducted to investigate biennial bearing; however, it remains a complicated problem (Bangerth, 2009; Elsysy and Hirst, 2017; Monselise and Goldschmidt, 1982). A number of highvalue apple cultivars exhibit biennial bearing, including Cameo, Fuji, and Honeycrisp. Biennial bearing is affected by a number of factors such as growth and development processes, plant growth regulators, carbohydrate content, and fruiting (Greene, 1996; Singh, 1948). These factors may interact at both the spur and whole-tree levels. Furthermore, fruit, and especially seeds within the fruit, appeared to be the major stimuli to biennial bearing (Chan and Cain, 1967; Dennis, 1967). Seeds may increase the demand by fruit for resources such as nutrients, plant growth regulators, and carbohydrates (Heinicke, 1917). This demand by the fruit for resources within the spurs could affect spur quality and flower formation.

Received for publication 10 Aug. 2018. Accepted for publication 29 Oct. 2018. We thank pomology lab members Andres Mayorga, Fatemeh Sheibani, Songwen Zhang, and Bofan Xie for their help in the different phases of the experiment. We also thank Cary Mitchell and Celina Gomez for their help with the gas exchange measurements.

${ }^{1}$ Corresponding author. E-mail: hirst@purdue.edu.
Previously, spur quality has been measured in terms of leaf area, spur leaf number, leaf dry weight, specific leaf weight, and mean leaf size (Barritt et al., 1987; Ferree, 1989). Total spur leaf area varies among cultivars and relates to tree productivity and efficiency (Rom and Ferree, 1984). Leaf area per spur has a quantitative relationship with flower formation (Rom and Barritt, 1990), and spur density is correlated with yield efficiency (Warrington et al., 1990). Spur characteristics are impacted by rootstocks (Hirst and Ferree, 1995a; Warrington et al., 1990), and spur quality was improved by the application of triazole compounds (Ferree and Schmid, 1987). Hence, spur morphological and anatomical attributes may be a way to study the effects of fruiting on spur quality and flower formation.

Four main genomic regions, containing floral genes, gibberellin oxidase genes, and meristem identity genes, associated with biennial bearing were identified in the genome of apple using quantitative trait locus analysis (Guitton et al., 2012). Homologs of the floral promoter Flowering Locus $T$ and the floral inhibitor Terminal Flower 1 were characterized in several fruit species including apple (Kotoda and Wada, 2005; Kotoda et al., 2006; Mimida et al., 2013). Plant growth regulators have been suggested to play a key role in bud development and flower formation in apple (Xing et al., 2015).

Leaves play several roles; they provide carbohydrates and plant growth regulators, and work as the main receptors for 
Table 1. Apple trees growing in Lafayette, IN, used in this study of the effect of fruiting and biennial bearing potential on spur quality and leaf gas exchange in apple. Bearing classification was based on experience with these cultivars.

\begin{tabular}{lclc}
\hline Cultivar & Yr planted & Rootstock & Bearing classification \\
\hline Fuji & 2001 & B.9 & Biennial \\
Gala & 2001 & B.9 & Annual \\
Golden Delicious & 2000 & G.16 & Biennial \\
Honeycrisp & 2003 & M.7 & Biennial \\
Pink Lady & 1999 & M.9 EMLA & Annual \\
Ruby Jon & 2001 & B.9 & Annual
\end{tabular}

A

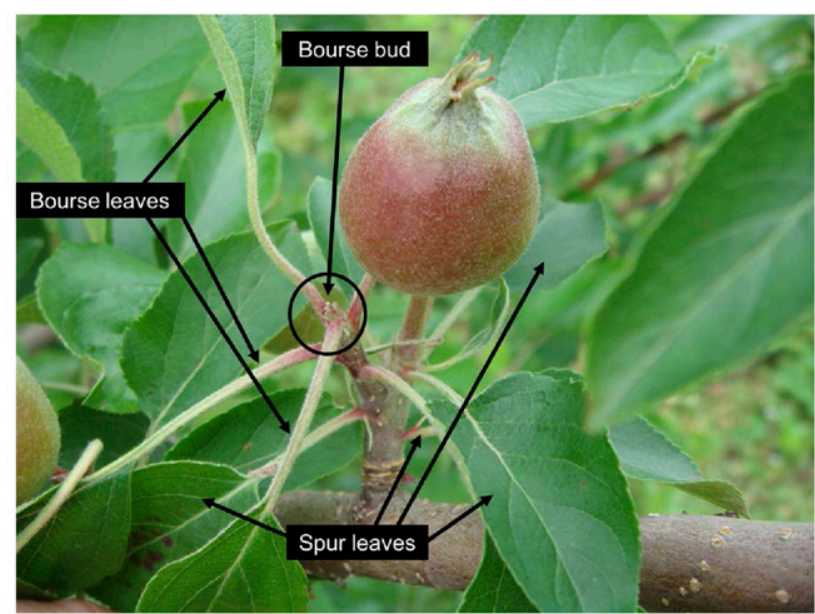

B

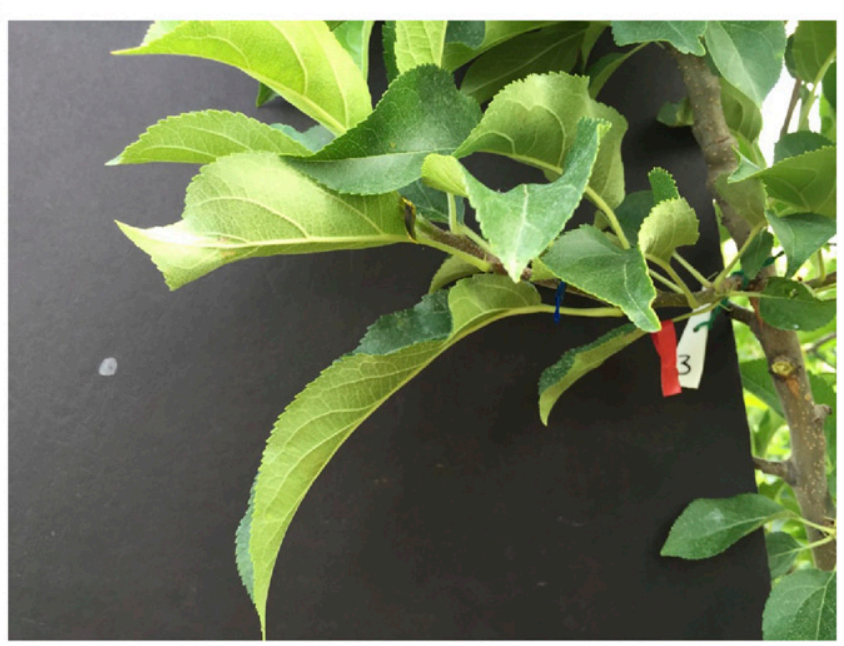

Fig. 1. (A) Apple fruiting spur showing spur leaves emerging directly from the spur, and bourse leaves emerging from the bourse shoot. (B) Leaves on 1 -year-old shoot.

environmental stimuli (Hanke et al., 2007). In addition, leaves transpire and affect the flow of substances through the xylem stream. In temperate deciduous trees, stomatal density correlates positively with transpiration and photosynthetic potential (Aasamaa et al., 2001; Sack et al., 2003, 2005). Moreover, stomatal density varies among apple cultivars (Cowart, 1936; Slack, 1974; Warrit et al., 1980). Fruiting affects several physiological processes in the leaves. For instance, in different fruit tree types, fruit-bearing trees showed increased $\mathrm{CO}_{2}$ assimilation rates compared with nonfruit-bearing trees (Palmer et al., 1991; Syvertsen et al., 2003; Urban et al.,
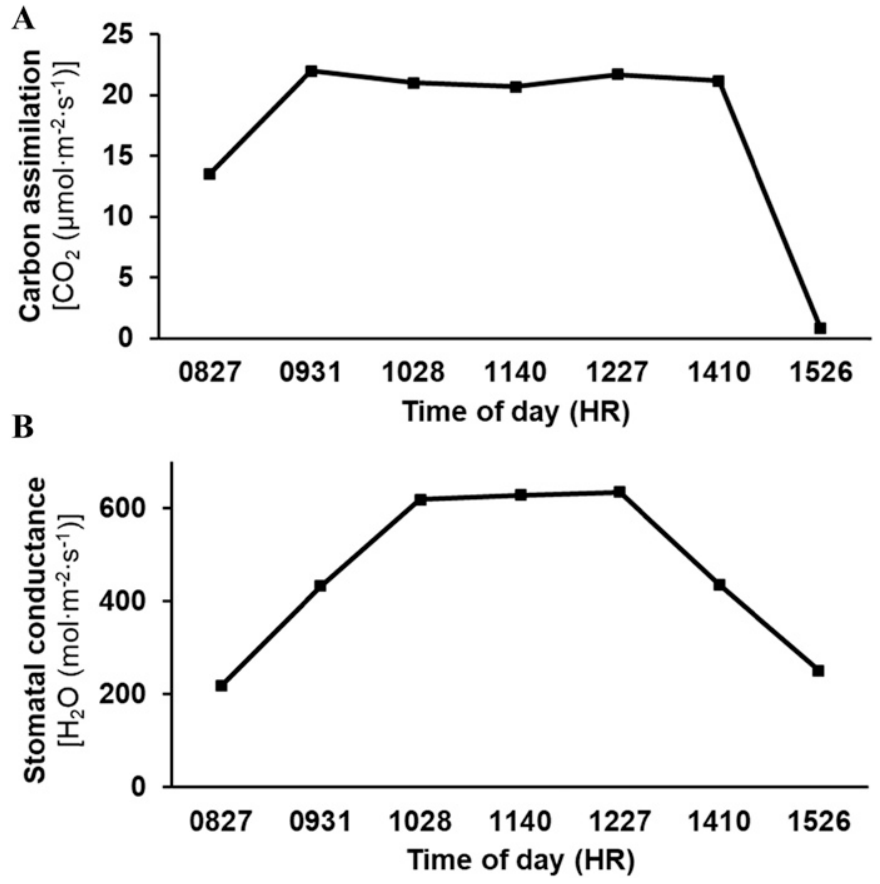

Fig. 2. Gas exchange of 'Honeycrisp' apple leaves measured throughout the day $\approx 2$ months after full bloom in Lafayette, IN. (A) $\mathrm{CO}_{2}$ assimilation rate. (B) Stomatal conductance.

2004). However, no differences in $\mathrm{CO}_{2}$ assimilation rates were observed in cherry (Prunus avium) and sweet orange (Citrus sinensis) between on and off crop years within the same cultivars (Monerri et al., 2011; Nebauer et al., 2013; Roper et al., 1988). A reduction in photoassimilate utilization was accompanied by the accumulation of nonstructural carbohydrates, especially starch, in 'Braeburn' apple leaves bearing low or no crop load (Wünsche et al., 2005). This reduction may have been induced by plant growth regulators or it may be a response to a change in intercellular $\mathrm{CO}_{2}$ concentrations. Moreover, the availability of photoassimilates could possibly play a regulatory role in floral induction (Shalom et al., 2012).

The relationship between carbohydrate content and flower formation has been well defined for a number of crops. For example, fruit removal of 'Wilking' mandarin (Citrus reticulata) by midsummer led to an increase in starch content and flower formation (Goldschmidt and Golomb, 1982). In 'Murcott' mandarin, defruiting affected the expression of genes related to photosynthesis, flower formation genes, and flower formation (Shalom et al., 2014). Sugar has been suggested to be a florigenic substance in plants (Ortiz-Marchena et al., 2015; Wahl et al., 2013). In addition, the network of flower formation in apple was suggested to be mediated by the crosstalk between sugar and plant growth regulator signals (Xing et al., 2015).

The objective of our experiment was to compare spur quality and flower formation of single-fruited and defruited spurs of annual and biennial apple cultivars. We hypothesized that defruiting would have a greater stimulating effect on flowering of biennial bearing cultivars than annual bearing cultivars, and that spur quality attributes that lead to greater spur carbohydrate levels will be associated with greater levels of flowering. 


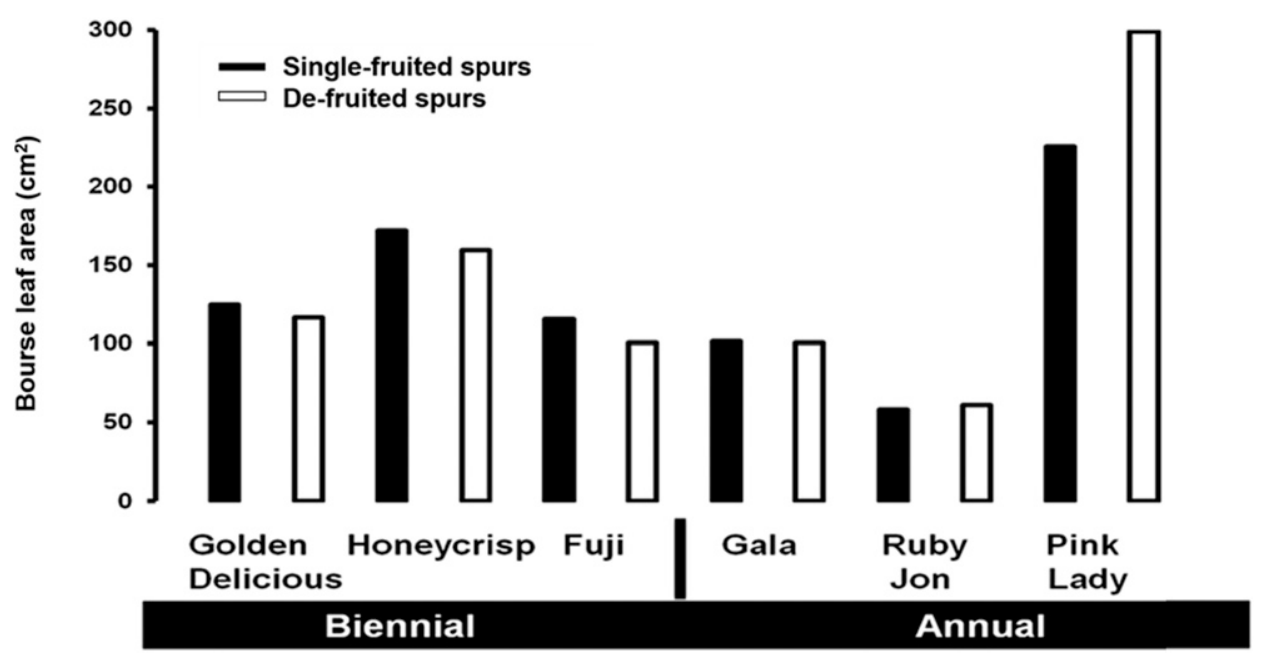

Fig. 3. Total bourse leaf area as affected by cultivar and fruiting treatment at the end of the 2014 growing season. Analysis of variance within every cultivar showed no significant effects of fruiting on total bourse leaf area during Summer 2014 for any of the six apple cultivars. (less than a 400-m spread). Growing conditions, including soil type, and tree management were similar for all trees. Within each cultivar, fruiting treatments were arranged as a completely randomized design. Four healthy trees of each cultivar were chosen and 120 flowering spurs were selected randomly at bloom across the four trees. At petal fall, 60 of these spurs were thinned to king flower only, whereas the other 60 selected spurs were completely defruited. All spurs were tagged using durable plastic tags identified by color and number. For each cultivar and treatment, 60 spurs from each cultivar and treatment were collected at the end of the growing season, $150 \mathrm{~d}$ after full bloom.

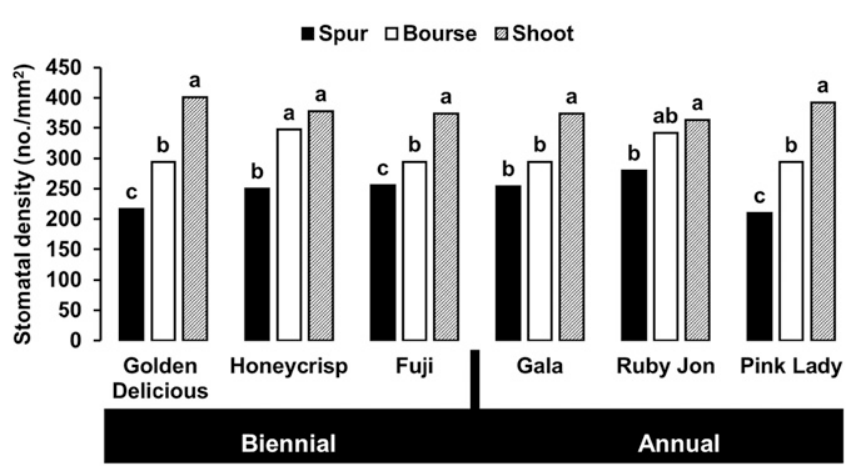

Fig. 4. Stomatal density of spur, bourse, and shoot leaves of six apple cultivars measured toward the end of the 2014 growing season. No significant differences existed between defruited and fruited spurs, so data were pooled within each cultivar. Different letters represent significant differences $(P<$ 0.05 ) among different leaf types within each cultivar.

\section{Materials and Methods}

Plant materials. This experiment was conducted in Spring 2014 on six apple cultivars, three generally considered to be annual bearing (Gala, Pink Lady, and Ruby Jon) and three generally considered to have greater biennial bearing potential (Fuji, Honeycrisp, and Golden Delicious) (Table 1). All cultivars were planted with $3 \times 5 \mathrm{~m}$ spacing at the Samuel G. Meigs Horticulture Facility of Purdue University in Lafayette, IN.

This experiment used mature trees growing on dwarfing 'Budagovsky 9' (B.9) or semidwarfing ['Geneva 16' (G.16), 'Malling 9' (M.9 EMLA), and 'Malling 7 EMLA' (M.7)] rootstocks (Table 1). All trees chosen for this study appeared healthy and were 3 to $5 \mathrm{~m}$ tall regardless of rootstock. Trees were trained to a vertical axis tree form and were managed according to standard commercial practices. Crop load was adjusted manually by hand-thinning at petal fall to achieve a medium crop load of 120-140 fruit per tree to avoid possible effects of excessive crop load on leaf gas exchange (Neilsen et al., 2016).

EXPERIMENTAL PROCEDURE. All trees were located at the same experimental farm within close proximity to each other

\section{Measurements}

Anatomical measurements. The following measurements were made on sampled spurs: 1) spur and bourse leaf number and leaf area (LI-3000; LI-COR, Lincoln, NE), 2) stomatal density, and 3) flower formation [examined under a dissecting microscope (SZ-STS; Olympus Corp., Center Valley, PA)] to determine flower formation for each bourse (Hirst and Ferree, 1995b).

Stomatal Density. Stomatal density of spur, bourse, and shoot leaves was measured from five single-fruited and five defruited spurs (Fig. 1). Abaxial epidermal anatomy was characterized on the second fully developed bourse and spur leaf. The abaxial epidermis adjacent to the leaf midrib was placed initially onto a cyanoacrylate droplet on a glass slide for $2 \mathrm{~s}$ to remove trichromes, then was placed on another cyanoacrylate droplet for $30 \mathrm{~s}$ to imprint the abaxial epidermis. Four images from different spots of each imprint were obtained from each slide under $200 \times$ magnification using a generic description microscope (OptiPhot2; Nikon, Tokyo, Japan) and microscope camera software MiniSee (Scopetek Electric Co., Hangzhou, China). In all calculations, stomata were considered to be a pair of fully developed guard cells. Stomata were counted using Image J software (National Institutes of Health, Bethesda, MD) and are expressed per square millimeter leaf area.

LEAF GAS EXCHANGE. Leaf gas exchange was measured on the third fully expanded, attached bourse leaf on three singlefruited and three defruited spurs in well-illuminated positions on the west side of the trees. Measurements were transpiration, $g_{\mathrm{S}}$, internal $\mathrm{CO}_{2}$ concentration, assimilation, and water use efficiency (WUE). All measurements were taken $66 \mathrm{~d}$ after full bloom on a sunny day of $\approx 24{ }^{\circ} \mathrm{C}$ between 0930 and $1430 \mathrm{HR}$. The optimal time of day was based on steady rates of assimilation and $g_{S}$ found during a pilot study on 'Honeycrisp' trees by measuring the same leaf throughout the day (Fig. 2). Measurements were taken using a portable infrared gas analyzer system (CIRAS-3; PP Systems, Amesbury, MA) fitted with a $4.5-\mathrm{cm}^{2}$ leaf chamber with built-in light emitting diodes (LEDs; 475-, 528-, 625-, and 425-650-nm peak wavelengths for the blue, green, red, and white LEDs, respectively). The conditions were reference $\mathrm{CO}_{2}$ concentration, $400 \mu \mathrm{mol} \cdot \mathrm{mol}^{-1}$; 


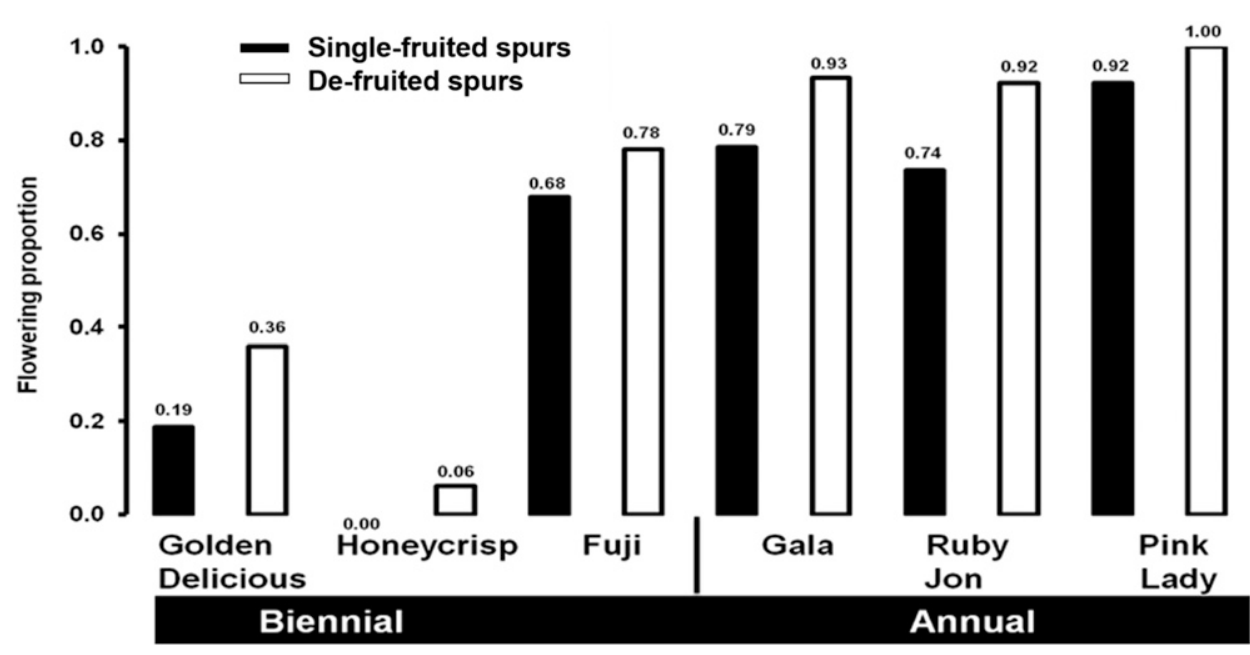

Fig. 5. The effect of fruiting on flower formation in six apple cultivars during Summer 2014. Logistic regression analysis within each cultivar showed no significant effect of single fruiting on bourse flower formation compared with defruited spurs. Flower formation is presented as a proportion of flowering spurs within each treatment for each cultivar

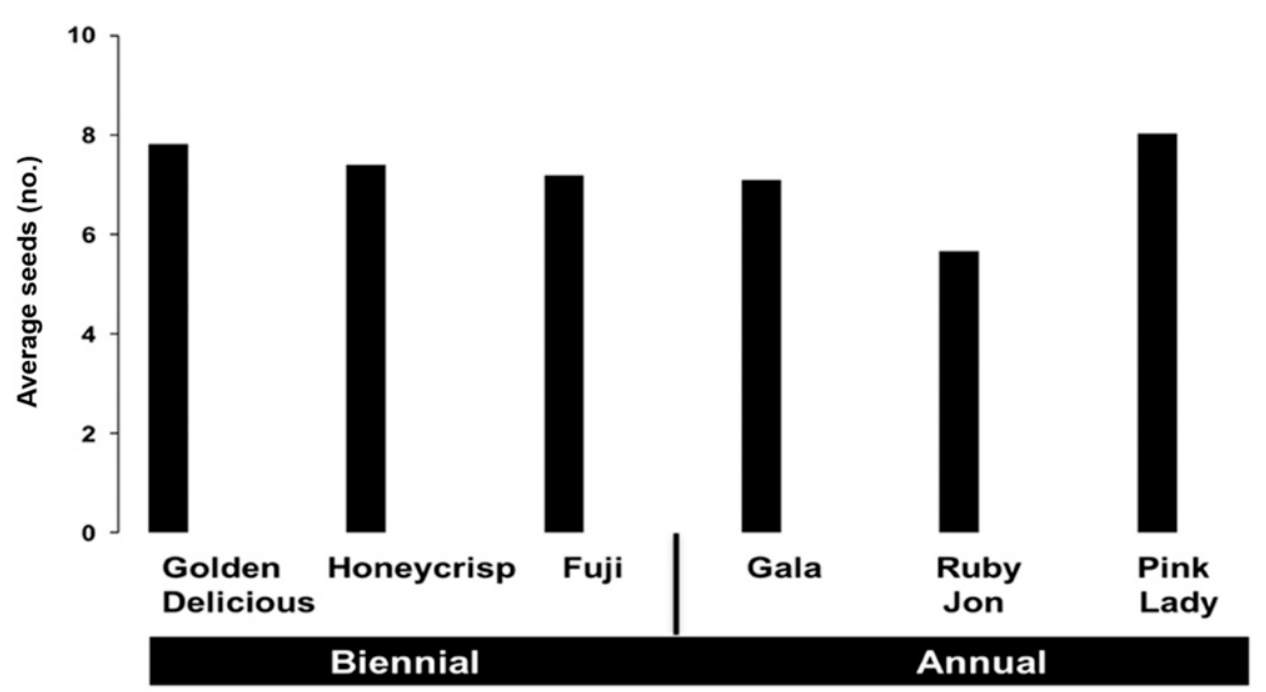

Fig. 6. Average seed number per fruit of annual and biennial apple cultivars growing in Lafayette, IN, during 2014. spurs compared with defruited spurs of the same cultivar (Fig. 3). There was also no relationship between the bearing potential of these cultivars and bourse leaf area. For example, both 'Pink Lady' and 'Ruby Jon' are characterized as annual bearing cultivars, but there was a trend for 'Pink Lady' to have the greatest bourse leaf area and for 'Ruby Jon' to have the lowest among all cultivars in this study (Fig. 3).

Stomatal Density. In all cultivars, the presence of fruit did not affect spur or bourse leaf stomatal density. Therefore, data from defruited and single-fruited spurs were combined. In all cultivars, shoot leaves had greater stomatal density than spur leaves, with bourse leaves tending to be intermediate (Fig. 4). There were no differences between biennial cultivars as a group and annual bearing cultivars.

FlOWER FORMATION. In all cultivars, there was no significant effect of fruiting on flower formation, although there was a trend in every cultivar for fruiting spurs to exhibit less flowering (Fig. 5). Biennial cultivars generally exhibited a decreased flowering proportion compared with annual cultivars. Fruit of both annual and biennial cultivars contained six to eight seeds per fruit, and no differences in seed number between annual and biennial cultivars was observed (Fig. 6). In addition, there was no effect of seed number on flower formation within any of the cultivars.

EFFECTS OF SINGLE FRUITING ON LEAF GAS EXCHANGE PARAMETERS. The presence of fruit had no effect leaf temperature, $25^{\circ} \mathrm{C}$; relative humidity, $\approx 60 \%$; and flow rate through the chamber, $300 \mathrm{~mL} \cdot \mathrm{min}^{-1}$. To determine the lightsaturated rates of photosynthesis, $g_{\mathrm{S}}$, transpiration, respiration, and WUE, the light unit in the cuvette was programmed to provide $1000 \mu \mathrm{mol} \cdot \mathrm{m}^{-2} \cdot \mathrm{s}^{-1}$ (33\% red light, 33\% blue light, and $34 \%$ green light). Measurements were recorded after reaching a steady state $(\approx 90 \mathrm{~s})$.

Statistical analysis. Analysis of variance and mean separation of parameters between defruited and single-fruited spurs were performed for all data. However, a binomial logistic regression with mixed-effects model was used to test flower formation. All data analyses were performed using R software version 3.2.2 (14 Aug. 2015) "Fire Safety" in the R statistical package (R Foundation, Vienna, Austria).

\section{Results}

EFFECTS OF FRUITING ON ANATOMICAL AND MORPHOLOGICAL CHARACTERISTICS. Bourse leaf area was not different in fruiting on leaf gas exchange in any of the studied cultivars (Table 2). Furthermore, WUE was unaffected by fruiting on single-fruited spurs compared with defruited spurs on the same trees (Elsysy and Hirst, unpublished data). However, both transpiration and $g_{\mathrm{S}}$ were greater in biennial cultivars compared with annual cultivars. Furthermore, analyses using Pearson correlation coefficients among different gas exchange processes revealed significant correlation coefficients $(P<0.05)$ between the following: 1) transpiration with $g_{\mathrm{S}}$, internal $\mathrm{CO}_{2}$ concentration, and assimilation; and 2) WUE with internal $\mathrm{CO}_{2}$ concentration and stomatal density (Table 3$)$. Significant correlation coefficients $(P<$ $0.05)$ occurred between flower formation and both transpiration and $g_{\mathrm{S}}[r=-0.61$ and -0.62 , respectively (Fig. 7)].

\section{Discussion}

Theories to explain the effect of fruiting on flower formation generally fall into three categories: 1) plant growth regulators (Guitton et al., 2012; Krasniqi et al., 2013; Pellerin et al., 2012), 
Table 2. Effect of fruiting, bearing potential, and their interaction on gas exchange in six apple cultivars.

\begin{tabular}{|c|c|c|c|c|c|}
\hline Bearing & Cultivar & Single fruited & Defruited & $\overline{\mathrm{X}}$ cultivar & $P$ value \\
\hline \multicolumn{6}{|c|}{ Transpiration $\left[\mathrm{H}_{2} \mathrm{O}\left(\mathrm{mmol} \cdot \mathrm{m}^{-2} \cdot \mathrm{s}^{-1}\right]\right.$} \\
\hline \multirow[t]{4}{*}{ Biennial } & Honeycrisp & 2.47 & 2.93 & 2.7 & 0.40 \\
\hline & Golden Delicious & 3.26 & 3.06 & 3.16 & 0.82 \\
\hline & Fuji & 2.77 & 2.47 & 2.62 & 0.33 \\
\hline & Biennial mean & 2.83 & 2.82 & 2.83 & \\
\hline \multirow[t]{7}{*}{ Annual } & Ruby Jon & 2.83 & 2.66 & 2.75 & 0.64 \\
\hline & Pink Lady & 2.09 & 2.26 & 2.18 & 0.75 \\
\hline & Gala & 2.24 & 2.26 & 2.25 & 0.96 \\
\hline & Annual mean & 2.39 & 2.40 & 2.39 & \\
\hline & Fruiting $(\mathrm{F})$ & & & & 0.98 \\
\hline & Bearing (B) & & & & $0.04 * z$ \\
\hline & $\mathrm{F} \times \mathrm{B}$ & & & & 0.95 \\
\hline \multicolumn{6}{|c|}{ Carbon assimilation $\left[\mathrm{CO}_{2}\left(\mu \mathrm{mol} \cdot \mathrm{m}^{-2} \cdot \mathrm{s}^{-1}\right)\right]$} \\
\hline \multirow[t]{4}{*}{ Biennial } & Honeycrisp & 15.67 & 20.27 & 17.97 & 0.14 \\
\hline & Golden Delicious & 21.97 & 22.20 & 22.09 & 0.87 \\
\hline & Fuji & 16.17 & 17.83 & 17 & 0.56 \\
\hline & Biennial mean & 17.94 & 20.1 & 19.02 & \\
\hline \multirow[t]{8}{*}{ Annual } & Ruby Jon & 18.87 & 19.17 & 19.02 & 0.89 \\
\hline & Pink Lady & 19.77 & 18.40 & 19.09 & 0.59 \\
\hline & Gala & 15.90 & 16.17 & 15.85 & 0.91 \\
\hline & Annual mean & 17.88 & 17.91 & 17.9 & \\
\hline & $\mathrm{F}$ & & & & 0.38 \\
\hline & $\mathrm{B}$ & & & & 0.36 \\
\hline & $\mathrm{F} \times \mathrm{B}$ & & & & 0.26 \\
\hline & Stom & conductance $[\mathrm{H}$ & $\mathrm{mol} \cdot \mathrm{m}^{-2} \cdot \mathrm{s}^{-1}$ & & \\
\hline \multirow[t]{4}{*}{ Biennial } & Honeycrisp & 263.3 & 396.0 & 329.65 & 0.40 \\
\hline & Golden Delicious & 435.3 & 437.0 & 436.15 & 0.82 \\
\hline & Fuji & 331.3 & 251.7 & 291.5 & 0.34 \\
\hline & Biennial mean & 343.3 & 361.57 & 352.43 & \\
\hline \multirow[t]{7}{*}{ Annual } & Ruby Jon & 326.3 & 291.3 & 308.8 & 0.68 \\
\hline & Pink Lady & 252.3 & 269.0 & 260.65 & 0.75 \\
\hline & Gala & 227.7 & 230.0 & 228.85 & 0.96 \\
\hline & Annual mean & 268.77 & 263.43 & 266.1 & \\
\hline & $\mathrm{F}$ & & & & 0.90 \\
\hline & $\mathrm{B}$ & & & & $0.05^{*}$ \\
\hline & $\mathrm{F} \times \mathrm{B}$ & & & & 0.8 \\
\hline
\end{tabular}

*Significant at $P \leq 0.05$.

Table 3. Correlation coefficients among leaf gas exchange, stomatal density, leaf area, and flower formation of six apple cultivars in Summer 2014.

\begin{tabular}{lccccccc}
\hline & Flowering $^{\mathrm{z}}$ & $\mathrm{E}$ & $g_{\mathrm{S}}$ & $\mathrm{Ci}$ & $\mathrm{A}$ & WUE & Stomatal density \\
\hline $\mathrm{E}$ & $-0.61^{*}$ & & & & & & \\
$g_{\mathrm{S}}$ & $-0.62^{*}$ & $0.93^{* * *}$ & & & & & \\
$\mathrm{Ci}$ & -0.51 & $0.59^{*}$ & 0.42 & & & & \\
$\mathrm{~A}$ & -0.27 & $0.64^{*}$ & $0.78^{* *}$ & -0.15 & & & \\
WUE & -0.36 & -0.42 & -0.15 & $-0.81^{* * *}$ & 0.39 & & \\
Stomatal density & -0.16 & 0.21 & 0.06 & 0.52 & -0.31 & $-0.62^{*}$ & \\
Leaf area & 0.02 & -0.37 & -0.14 & -0.20 & 0.05 & $0.56^{*}$ & -0.33 \\
\hline Z & & & & & & & \\
\hline
\end{tabular}

${ }^{\mathrm{z}}$ Flowering $=$ flower formation.

$*$, **, ***Significant at $P \leq 0.05,0.01$, or 0.001 , respectively.

$\mathrm{E}=$ transpiration; $g_{\mathrm{S}}=$ stomatal conductance; $\mathrm{Ci}=$ internal $\mathrm{CO}_{2}$ concentration; $\mathrm{A}=$ assimilation; WUE $=$ water use efficiency.

2) source-sink competition (Bruchou and Génard, 1999; Palmer et al., 1991; Saa and Brown, 2014), and 3) the interaction between plant growth regulators and sink-source competition (Smith and Samach, 2013; Untiedt and Blanke, 2001).
In a related experiment on flower formation in 'Honeycrisp' apple, we found greater flower formation on single-fruited spurs compared with those bearing two fruit (M.A. Elsysy and P.M. Hirst, unpublished data). Hence, in the current study, we examined the effect of bearing a single fruit on spur quality and flower formation of annual and biennial cultivars. In contrast to our previous results with double-fruited spurs, in this experiment we found that singlefruited spurs showed similar spur characteristics and flower formation to nonfruiting spurs in both annual and biennial cultivars (Table 2; Figs. 3-5). Apparently, single fruiting did not stimulate the local inhibition effects previously suggested by plant growth regulators, source-sink competition, or their interaction.

Fruiting affects several leaf physiological processes (Palmer et al., 1991; Syvertsen et al., 2003; Urban et al., 2004). However, the combined effects of individual spur fruiting and cultivar bearing potentials on leaf anatomy and physiological processes have not been examined. In this study, we propose that annual and biennial cultivars possess different photoassimilation strategies, because both $g_{\mathrm{S}}$ and transpiration were greater in biennial cultivars compared with annual cultivars (Table 2; Fig. 7). Stomatal density was found previously to be correlated with transpiration in a transgenic apple species (Liao et al., 2017), although no such relationship was found in the current study (Table 3) and no differences in stomatal density were found among cultivars (Fig. 4). Transpiration was closely related to $g_{\mathrm{S}}$ but not stomatal density (Table 3 ). Hence, it would seem that differences in $g_{\mathrm{S}}$, and resultant transpiration rates among these cultivars, may influence flower formation (Fig. 7).

In addition, both $g_{\mathrm{S}}$ and transpiration correlated positively with assimilation (Table 3). Hence, we suggest that high $g_{\mathrm{S}}$ and transpiration rates in biennial cultivars may affect flower formation via 1) different consumption rates of photoassimilates in biennial cultivars that could affect the sink-source relationship, 2) change in the balance of plant growth regulators, and 3) higher xylem flow in biennial cultivars compared with annual cultivars. Actually, the newly well-defined interaction among sugar, photoassimilates, and the expression level of flower formation genes in citrus (Shalom et al., 2014) and 
A

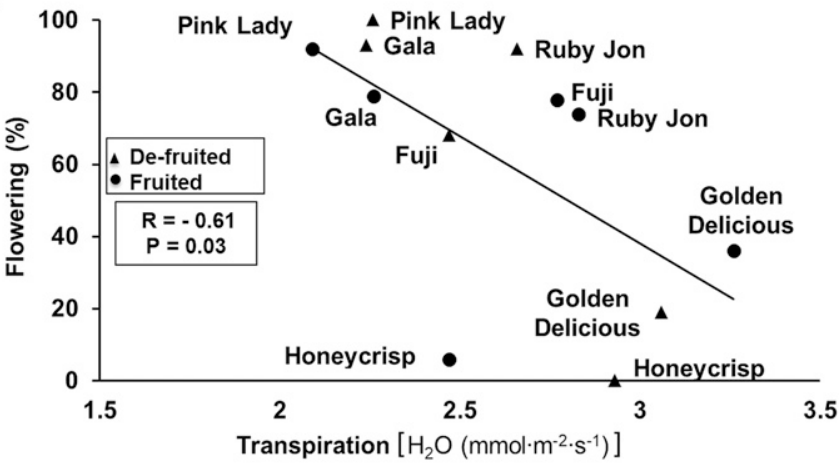

B

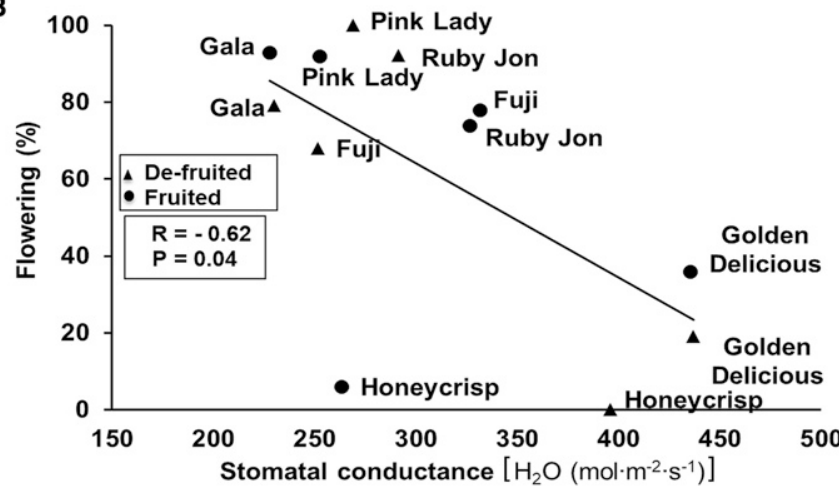

Fig. 7. Relationship between flower formation and (A) transpiration and (B) stomatal conductance in six apple cultivars during Summer 2014. Flowering (measured as a percentage) represents the proportion of flower formation for each treatment in each cultivar.

apple (Xing et al., 2015) suggests that transpiration and $g_{\mathrm{S}}$ may influence flower formation by affecting photoassimilates or sugar levels. Differences found here in transpiration rates between biennial and annual bearing cultivars, and the relationship between transpiration rates and flowering, are likely the result of changes in plant growth regulators transported in the xylem, because no differences in assimilation were found (Table 2; Fig. 7).

In conclusion, this research shows that in both annual and biennial cultivars, bearing a single fruit per spur does not necessarily inhibit flower formation for the following year's crop when the overall tree crop load is not excessive. Based on the three biennial and three annual cultivars studied in this experiment, different bearing types appear to have different gas exchange characteristics, with biennial cultivars having greater $g_{S}$ and transpiration rates. Further research on the effects of different transpiration and $g_{\mathrm{S}}$ rates on xylem flow, and the expression patterns of photosynthesis genes, plant growth regulator genes, and flowering genes in buds of annual and biennial cultivars could explain the complicated networks involved in apple flower formation.

\section{Literature Cited}

Aasamaa, K., A. Sober, and M. Rahi. 2001. Leaf anatomical characteristics associated with shoot hydraulic conductance, stomatal conductance and stomatal sensitivity to changes of leaf water status in temperate deciduous trees. Austral. J. Plant Physiol. 28:765-774. Bangerth, K.F. 2009. Floral induction in mature, perennial angiosperm fruit trees: Similarities and discrepancies with annual/biennial plants and the involvement of plant hormones. Scientia Hort. 122:153-163. Barritt, B.H., C.R. Rom, K.R. Guelich, S.R. Drake, and M.A. Dilley. 1987. Canopy position and light effects on spur, leaf, and fruit characteristics of 'Delicious' apple. HortScience 22:402-405.
Bruchou, C. and M. Génard. 1999. A space-time model of carbon translocation along a shoot bearing fruits. Ann. Bot. 84:565-576.

Chan, B. and J. Cain. 1967. The effect of seed formation on subsequent flowering in apple. J. Amer. Soc. Hort. Sci. 91:63-67.

Cowart, F.F. 1936. Apple leaf structure as related to position of the leaf upon the shoot and to type of growth. Proc. Amer. Soc. Hort. Sci. 33:145-148.

Dennis, F.G. 1967. Apple fruit-set: Evidence for a specific role of seeds. Science 156(3771):71-73.

Elsysy, M.A. and P.M. Hirst. 2017. The role of spur leaves, bourse leaves, and fruit on local flower formation in apple: An approach to understanding biennial bearing. HortScience 52:1229-1232.

Ferree, D.C. 1989. Influence of orchard management systems on spur quality, light and fruit within the canopy of 'Golden Delicious' apple trees. J. Amer. Soc. Hort. Sci. 114:869-875.

Ferree, D.C. and J.C. Schmid. 1987. Influence of growth regulators on apple spur quality and tree performance, p. 1-6. In: Fruit crops 1987: A summary of research. Ohio State Univ. Res. Circ. 295.

Goldschmidt, E.E. and A. Golomb. 1982. The carbohydrate balance of alternate-bearing citrus trees and the significance of reserves for flowering and fruiting. J. Amer. Soc. Hort. Sci. 107:206-208.

Greene, D.W. 1996. Flower development, p. 91-98. In: K. Maib, P. Andrews, G. Lang, and K. Mullinix (eds.). Tree fruit physiology: Growth and development. Good Fruit Grower, Yakima, WA.

Guitton, B., J.J. Kelner, R. Velasco, S.E. Gardiner, D. Chagné, and E. Costes. 2012. Genetic control of biennial bearing in apple. J. Expt. Bot. 63:131-149.

Hanke, M.V., H. Flachowsky, A. Peil, and C. Hättasch. 2007. No flower no fruit: Genetic potentials to trigger flowering in fruit trees. Genes Genomes Genomics 1:1-20.

Heinicke, A.J. 1917. Factors influencing the abscission of flowers and partially developed fruits of the apple (Pyrus malus L.). PhD thesis. Cornell Univ. Agr. Expt. Sta. Bul. 393.

Hirst, P.M. 2017. Advances in understanding flowering and pollination in apple trees, p. 109-126. In: K. Evans (ed.). Achieving sustainable cultivation of apples. Burleigh Dodds Scientific Publishing, Cambridge, UK.

Hirst, P.M. and D.C. Ferree. 1995a. Rootstock effects on shoot morphology and spur quality of 'Delicious' apple and relationships with precocity and productivity. J. Amer. Soc. Hort. Sci. 120:622634.

Hirst, P.M. and D.C. Ferree. 1995b. Rootstock effects on the flowering of 'Delicious' apple: I. Bud development. J. Amer. Soc. Hort. Sci. 120:1010-1017.

Kotoda, N., H. Iwanami, S. Takahashi, and K. Abe. 2006. Antisense expression of MdTFL1, a TFL1-like gene, reduces the juvenile phase in apple. J. Amer. Soc. Hort. Sci. 131:74-81.

Kotoda, N. and M. Wada. 2005. MdTFL1, a TFL1-like gene of apple, retards the transition from the vegetative to reproductive phase in transgenic Arabidopsis. Plant Sci. 168:95-104.

Krasniqi, A.L., L. Damerow, A. Kunz, and M.M. Blanke. 2013. Quantifying key parameters as elicitors for alternate fruit bearing in cv. 'Elstar' apple trees. Plant Sci. 212:10-14.

Liao, X., X. Guo, Q. Wang, Y. Wang, D. Zhao, L. Yao, S. Wang, G. Liu, and T. Li. 2017. Overexpression of MsDREB6.2 results in cytokinin-deficient developmental phenotypes and enhances drought tolerance in transgenic apple plants. Plant J. 89:510-526.

Mimida, N., S. Komori, A. Suzuki, and M. Wada. 2013. Functions of the apple TFL1/FT orthologs in phase transition. Scientia Hort. 156:106-112.

Monerri, C., A. Fortunato-Almeida, R.V. Molina, S.G. Nebauer, A. García-Luis, and J.L. Guardiola. 2011. Relation of carbohydrate reserves with the forthcoming crop, flower formation and photosynthetic rate, in the alternate bearing 'Salustiana' sweet orange (Citrus sinensis L.). Scientia Hort. 129:71-78.

Monselise, S.P. and E.E. Goldschmidt. 1982. Alternate bearing in fruit trees. Hort. Rev. 4:128-173. 
Nebauer, S.G., C. Arenas, J. Rodríguez-Gamir, Y. Bordón, A. Fortunato-Almeida, C. Monerri, J.L. Guardiola, and R.V. Molina. 2013. Crop load does not increase the photosynthetic rate in Citrus leaves under regular cropping conditions: A study throughout the year. Scientia Hort. 160:358-365.

Neilsen, D., G. Neilsen, S. Guak, and T. Forge. 2016. Consequences of deficit irrigation and crop load reduction on plant water relations, yield, and quality of 'Ambrosia' apple. HortScience 51:98-106.

Ortiz-Marchena, M.I., J.M. Romero, and F. Valverde. 2015. Photoperiodic control of sugar release during the floral transition: What is the role of sugars in the florigenic signal? Plant Signal. Behav. 10: e1017168.

Palmer, J.W., Y.L. Cai, and Y. Edjamo. 1991. Effect of part-tree flower thinning on fruiting, vegetative growth and leaf photosynthesis in 'Cox’s Orange Pippin' apple. J. Hort. Sci. 66:319-325.

Pellerin, B.P., D. Buszard, A. Georgallas, and R.J. Nowakowski. 2012. A novel framework to consider endogenous hormonal control of apple tree flowering. HortScience 47:589-592.

Rom, C.R. and B. Barritt. 1990. Spur development of 'Delicious' apple as influenced by position, wood age, strain, and pruning. HortScience 25:1578-1581.

Rom, C.R. and D.C. Ferree. 1984. Spur leaf characteristics of nine apple cultivars. Fruit Var. J. 38:2-5.

Roper, T.R., J.D. Keller, W.H. Loescher, and C.R. Rom. 1988. Photosynthesis and carbohydrate partitioning in sweet cherry: Fruiting effects. Physiol. Plant. 72:42-47.

Saa, S. and P.H. Brown. 2014. Fruit presence negatively affects photosynthesis by reducing leaf nitrogen in almond. Funct. Plant Biol. 41:884-891.

Sack, L., P.D. Cowan, N. Jaikumar, and N.M. Holbrook. 2003. The 'hydrology' of leaves: Co-ordination of structure and function in temperate woody species. Plant Cell Environ. 26:1343-1356.

Sack, L., M.T. Tyree, and N.M. Holbrook. 2005. Leaf hydraulic architecture correlates with regeneration irradiance in tropical rainforest trees. New Phytol. 167:403-413.

Shalom, L., S. Samuels, N. Zur, L. Shlizerman, A. Doron-Faigenboim, E. Blumwald, and A. Sadka. 2014. Fruit load induces changes in global gene expression and in abscisic acid (ABA) and indole acetic acid (IAA) homeostasis in citrus buds. J. Expt. Bot. 65: 3029-3044.

Shalom, L., S. Samuels, N. Zur, L. Shlizerman, H. Zemach, M. Weissberg, R. Ophir, E. Blumwald, and A. Sadka. 2012. Alternate bearing in citrus: Changes in the expression of flowering control genes and in global gene expression in ON- versus OFF-crop trees. PLoS One 7:e46930.

Singh, L.B. 1948. Studies in biennial bearing: III. Growth studies in "on" and "off" year trees. J. Hort. Sci. 24:123-148.

Slack, E.M. 1974. Studies of stomatal distribution on the leaves of four apple varieties. J. Hort. Sci. 49:95-103.

Smith, H.M. and A. Samach. 2013. Constraints to obtaining consistent annual yields in perennial tree crops. I: Heavy fruit load dominates over vegetative growth. Plant Sci. 207:158-167.

Syvertsen, J.P., C. Goñi, and A. Otero. 2003. Fruit load and canopy shading affect leaf characteristics and net gas exchange of 'Spring' navel orange trees. Tree Physiol. 23:899-906.

Untiedt, R. and M. Blanke. 2001. Effects of fruit thinning agents on apple tree canopy photosynthesis and dark respiration. Plant Growth Regulat. 35:1-9.

Urban, L., M. Léchaudel, and P. Lu. 2004. Effect of fruit load and girdling on leaf photosynthesis in Mangifera indica L. J. Expt. Bot. 55:2075-2085.

Wahl, V., J. Ponnu, A. Schlereth, S. Arrivault, T. Langenecker, A. Franke, R. Feil, J.E. Lunn, M. Stitt, and M. Schmid. 2013. Regulation of flowering by trehalose-6-phosphate signaling in Arabidopsis thaliana. Science 339(6120):704-707.

Warrington, I.J., D.C. Ferree, and J.R. Schupp. 1990. Strain and rootstock effects on spur characteristics and yield of 'Delicious' apple strains. J. Amer. Soc. Hort. Sci. 115:348-356.

Warrit, B., J.J. Landsberg, and M.R. Thorpe. 1980. Responses of apple leaf stomata to environmental factors. Plant Cell Environ. 3:13-22.

Wünsche, J.N., D.H. Greer, W.A. Laing, and J.W. Palmer. 2005. Physiological and biochemical leaf and tree responses to crop load in apple. Tree Physiol. 25:1253-1263.

Xing, L.B., D. Zhang, Y.M. Li, Y.W. Shen, C.P. Zhao, J.J. Ma, N. An, and M.Y. Han. 2015. Transcription profiles reveal sugar and hormone signaling pathways mediating flower induction in apple (Malus domestica Borkh.). Plant Cell Physiol. 56:2052-2068. 